\title{
KEMAMPUAN MEDIA PAPAN PAKIS SEBAGAI BIOFILTER DALAM MENURUNKAN KADAR BOD DAN COD PADA AIR LIMBAH PEMOTONGAN AYAM Juherah $^{1}$ dan Sirma Mangiri ${ }^{2}$ \\ 1,2JurusanKesehatanLingkunganPoltekkesKemenkes Makassar irenmangiri95@gmail.com
}

\begin{abstract}
Liquid waste that does not meet the specified quality standard can have an impact on the environment and health (causing certain diseases). To measure the quality of pollution is to measure the level of Biochemical Oxygen Demand (BOD) and Chemical Oxygen Demand (COD) parameters present in a liquid waste. The purpose of this research is to know the ability of fern board media in lowering BOD (Biochemical Oxygen Demand) and COD (Chemichal Oxygen Demand) on Cut Chicken Wastewater. This study aims to determine how big the biofilter ability of fern board media in lowering BOD and COD levels in Liquid House Waste Chicken Slaughter. This study is experimental, to determine the ability of fry board media filter as a breeding place of bacteria with the residence time of 11 hours. The results showed that BOD and COD content of chicken slaughter house waste after treatment with anaerobic and aerobic biofilter with three replication where the initial BOD content of 226,59 mg / I after treatment became $77,19 \mathrm{mg}$ / I, with percentage decrease equal to $65.93 \%$. On the treatment of 2 initial levels of $210.36 \mathrm{mg} / \mathrm{I}$ and after treatment decreased to $73.60 \mathrm{mg} / \mathrm{I}$ with a decrease percentage of $64.84 \%$ and replication 3 initially levels of $207.18 \mathrm{mg} / \mathrm{I}$ and decreased to $70.72 \mathrm{mg} / \mathrm{L}$ with a percentage decrease of $65.69 \%$. While the COD concentration at the initial replication level of $680 \mathrm{mg} / \mathrm{I}$ decreased to 160 $\mathrm{mg} / \mathrm{I}$, with a decrease percentage of $76.64 \%$ in replication 2 baseline $640 \mathrm{mg} / \mathrm{I}$ decreased to $140 \mathrm{mg} / \mathrm{I}$ with a decrease percentage of $78.13 \%$ And 3 initial treatment $610 \mathrm{mg} /$ I dropped to $100 \mathrm{mg} /$ I with a decrease percentage of $83.60 \%$. From the above result, the $\mathrm{BOD}$ and $\mathrm{COD}$ content have fulfilled the quality standard based on the Regulation of the State Minister of Environment Number 02 of 2006 where the BOD content is $100 \mathrm{mg} / \mathrm{I}$ and COD $200 \mathrm{mg} / \mathrm{I}$. It is suggested to the chicken cutting industry to do the processing before it is discharged into the water body environment.
\end{abstract}

Keywords: BOD, COD, Biofilter, Fern Board.

\section{ABSTRAK}

Limbah cair yang tidak memenuhi standart kualitas yang telah ditentukan dapat mempunyai pengaruh terhadap lingkungan dan kesehatan (menimbulkan beberapa penyakit tertentu). Untuk mengukur kualitas pencemarannya adalah mengukur kadar parameter Biochemical Oksigen Demand (BOD) dan Chemical Oxygen Demand (COD) yang ada pada suatu limbah cair.Tujuan dari penelitian ini adalah Untuk mengetahui kemampuan media papan pakis dalam menurunkan kadar BOD (Biochemical Oxygen Demand) dan COD (Chemichal Oxygen Demand) pada air limbah Pemotongan Ayam. Penelitian ini bertujuan untuk mengetahui seberapa besar kemampuan biofilter media papan pakis dalam menurunkan kadar BOD dan COD pada Limbah Cair Rumah Pemotongan Ayam. Penelitian ini bersifat Eksperimen,untuk mengetahi kemampuan media saring papan pakis sebagai tempat perkembangbiakkan bakteri dengan waktu tinggal 11 jam. Hasil penelitian menunjukkan bahwa kadar BOD dan COD limbah cair rumah pemotongan ayam setelah dilakukan pengolahan dengan biofilter anaerob dan aerob dengan tiga kali pemeriksaan dimana kadar BOD awal yaitu $226,59 \mathrm{mg} / \mathrm{l}$ setelah pengolahan menjadi $77,19 \mathrm{mg} / \mathrm{l}$, dengan persentase penurunan sebesar $65,93 \%$. pada pemeriksaan $2 \mathrm{kadar}$ awal 210,36 mg/l dan setelah perlakuan turun menjadi 73,60 mg/l dengan persentase penurunan sebesar $64,84 \%$ dan pemeriksaan 3 kadar awalnya yaitu $207,18 \mathrm{mg} / \mathrm{l}$ dan turun menjadi $70,72 \mathrm{mg} / \mathrm{l}$ dengan persentase penurunan sebasar $65,69 \%$. Sedangkan kadar COD pada pemeriksaan 1 kadar awal yaitu $680 \mathrm{mg} / \mathrm{l}$ turun menjadi $160 \mathrm{mg} / \mathrm{l}$, dengan persentase penurunan sebesar 76,64 \% pada pemeriksaan 2 kadar awal $640 \mathrm{mg} / \mathrm{l}$ turun menjadi $140 \mathrm{mg} / \mathrm{l}$ dengan persentase penurunan sebesar $78,13 \%$ dan pemeriksaan 3 kadar awal $610 \mathrm{mg} / \mathrm{l}$ turun menjadi $100 \mathrm{mg} / \mathrm{l}$ dengan persentase penurunan sebesar 83,60 \%. Dari hasil tersebut kadar BOD dan COD sudah memenuhi baku mutu berdasarkan Peraturan Menteri Negara Lingkungan Hidup nomor 02 tahun 2006 dimana kadar BOD yaitu 100 mg/l dan COD 200 mg/l. Adapun disarankan kepada pihak industri pemotongan ayam agar melakukan pengolahan sebelum dibuang ke lingkungan badan air.

Kata kunci : BOD, COD, Biofilter, Papan Pakis.

\section{PENDAHULUAN}

Berkembangnya kegiatan industri pemotongan ayam juga meningkatkan limbah yang terus meningkat serta membawa pengaruh dampak positif dan negatif bagi lingkungan maupun manusia, karena mengandung banyak mengandung bahan organik yang tinggi sehingga menghasilkan bau busuk.

Limbah usaha pemotongan ayam dapat menimbulkan pencemaran yang cukup berat, limbah pemotongan hewan sebagai limbah organik yang mengandung protein, karbodhidrat,lemak, dapat bertindak sebagai media pertumbuhan dan perkembangan mikroba sehingga mudah mengalami pembusukan. Dalam proses pembusukannya didalam air limbah, mengakibatkan terjadinya kenaikan parameter seperti BOD ( Biological Oxygen Demand) COD ( Chemical Oxygen Demand ) TSS ( Total Suspended Solid ) minyak dan lemak. Selain itu juga dapat menimbulkan gangguan estetika yaitu bau busuk, serta dapat menjadi tempat berkembang biaknya vector penyakit. Dengan kondisi seperti ini air limbah industri pemotongan ayam merupakan salah satu sumber pencemaran lingkungan bila tidak diolah sebelum di buang.

Oksigen terlarut pada air limbah dipengaruhi oleh kandungan bahan organik dari 
Jurnal Sulolipu : Media Komunikasi Sivitas Akademika dan Masyarakat

Vol. 17 No.II 2017

e-issn : 2622-6960, p-issn : 0854-624X

suatu limbah yang biasanya dinyatakan dengan parameter BOD atau "Biochemical Oxygen Demand". BOD dapat didefinisikan sebagai jumlah oksigen terlarut yang dikonsumsi atau digunakan oleh kegiatan kimia atau mikrobiologik, bila suatu contoh air diinkubasikan dalam keadaan gelap (biasanya 5 hari) pada suhu tertentu $\left(20^{\circ} \mathrm{C}\right)$. Oleh karena oksigen dibutuhkan untuk oksidasi bahan organik, maka BOD menunjukkan indikasi kasar banyaknya kandungan bahan organik dalam limbah tersebut (Jenie \& Rahayu, 1996). Sedangkan parameter COD atau "Chemical Oxygen Demand" merupakan kebutuhan oksigen dalam proses oksidasi secara kimia.

Biofilter berfungsi sebagai media penyaring air limbah, air limbah yang berasal dari industri pemotongan ayam dialirkan masuk kedalam bak pengendap awal untuk mengendapkan partikel dan kotoran organik tersuspensi.Air limpasan dari bak pengendap awal selanjutnya dialirkan ke bak kontraktor anaerob diisi dengan media papan pakis, penguraian zat organik yang ada didalam air limbah dilakukan oleh bakteri anaerobik. Setelah beberapa hari pada permukaan media filter akan tumbuh lapisan mikroorganisme.

Pakis merupakan salah satu jenis tanaman pohon yang memiliki dua jenis warna batang pakis yaitu warna hitam dan coklat. Tanaman pakis hitam ini lah yang sudah tidak asing dijadikan sebagai media tanam untuk beberapa jenis tanaman. Pakis hitam ini adalah batang yang sudah tua dan kering, dan mudah dibentuk menjadi potongan kecil sebagai cacahan pakis. Batang pakis juga digunakan sebagai media tanam berbentuk lempengan persegi yang siap pakai, namun kelemahannya media ini sering dikunjungi semut dan binatang lainnya. (Tjitrosoepomo, 1994)

Dari hasil penelitian yang telah dilakukan oleh Nusa Idaman Said (2005), yaitu uji performance biofilter anaerob unggun dengan menggunakan media biofilter plastik berbentuk sarang tawon untuk pengolahan air limbah pemotongan ayam dengan waktu tinggal $1-4$ hari dengan penurunan kadar BOD 85 - $90 \%$,dan kadar COD 86 - $90 \%$. Selanjutnya penelitian yang telah dilakukan oleh Andri Saputra dan M. Hasbi and Budijono (2008) Peningkatan Remediasi TSS dan TDS Air Limbah Rumah Potong Hewan Sapi Kota Pekanbaru dengan Proses Biofilter Kombinasi Anaerob - Aerob Bermedia Potongan Plastik untuk Media Hidup Ikan Budidaya, diperoleh penurunan efektivitas
TSS konsentrasi menurun selama lima observasi kali berkisar dari 38,78-52,88 \%.

Berdasarkan hal di atas maka penelti tertarik untuk melakukan peneltian dengan judul studi kemampuan media papan pakis sebagai media biofilter dalam menurunkan kadar BOD dan COD pada air limbah pemotongan ayam.

\section{BAHAN DAN METODE}

\section{Lokasi Penelitian}

Pengambilan sampel penelitian diambil dari limbah cair hasil kegiatan Usaha Pemotongan Ayam di kelurahan barah-baranya Kota Makassar.

\section{Desain dan Variabel Penelitian}

Jenis penelitian yang digunakan adalah eksperimen yaitu untuk mengetahui penurunan kadar BOD dan COD pada air limbah pemotongan ayam dengan pengolahan media papan pakis kombinasi aerob dan anaerob.

Variabel dalam penelitian ini adalah proses biofilter dengan menggunakan papan pakis dalam menurunkan kadar BOD dan COD air limbah pemotongan ayam dengan desain sebagai berikut:

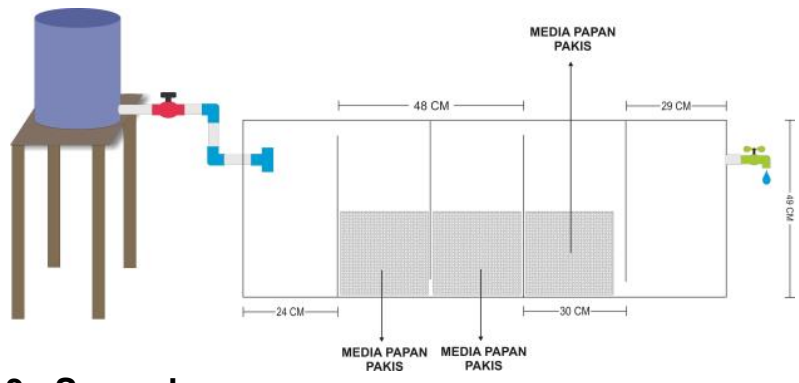

3. Sampel

Sampel dalam penelitian ini adalah air limbah pemotongan ayam arninda kelurahan Bara-baraya Kota Makassar.

\section{Pengumpulan Data}

a. Data Primer

Data primer merupakan data yang diperoleh dari hasil penelitian, serta analisa hasil pemeriksaan laboratorium tentang kandungan BOD dan COD dalam air limbah pemotongan ayam.

b. Data Sekunder

Data yang diperoleh melalui penelurusan kepustakaan, berupa bukubuku, referensi, jurnal dan hasil penelitian sebelumnya, dan penelitian literatur yang mendukung penelitian ini. 


\section{Analisis Data}

Dianalisa secarara deskriptif yaitu dengan mengetahui besarnya perbedaan penurunan kadar BOD dan COD setelah dialkukan perlakuan dengan menggunakan media papan pakis.

\section{HASIL PENELITIAN}

Setelah melakukan penelitian yang bertujuan untuk mengetahui seberapa besar kemampuan boifilter media papan pakis dalam menurunkan kadar BOD dan COD pada air limbah pemotongan ayam

\section{Hasil Pemeriksaan Kadar Awal BOD dan} COD

Hasil pemeriksaan air limbah yang dilaksanakan pada tanggal 16 Mei 2017 diperoleh kadar BOD awal sebesar 226,59 mg/l dan kadar COD awal sebesar $680 \mathrm{mg} / \mathrm{l} \mathrm{jika}$ dibandingkan dengan standar MENKLH RI. No. 02 Tahun 2006 Tentang Baku Mutu Air Limbah Bagi Kegiatan Rumah Pemotongan Hewan, khususnya untuk industry pemotongan ayam kadar BOD dan COD tersebut belum memenuhi syarat sesuai standar baku mutu, yaitu kadar maksimum BOD 100 mg/l dan COD $200 \mathrm{mg} / \mathrm{L}$.

2. Hasil Pemeriksaan Kadar BOD dan COD Setelah Pengolahan

Berdasarkan hasil penelitian yang telah dilakukan menggunakan metode biofilter dengan menggunakan media papan pakis, maka diperoleh hasil bahwa telah terjadi penurunan kadar BOD dan COD pada air limbah pemotongan ayam diperoleh hasil sebagai berikut:

Tabel 1

Hasil Pemeriksaan Kadar BOD Sampel Sebelum Dan Sesudah Pengolahan Biofilter Anaero Dan Aerob Dengan Media Papan Pakis Tahun 2017

\begin{tabular}{|c|c|c|c|c|c|}
\hline \multirow{2}{*}{$\begin{array}{l}\mathbf{N} \\
\mathbf{0}\end{array}$} & \multirow{2}{*}{$\begin{array}{l}\text { Pemeriksa } \\
\text { an }\end{array}$} & \multicolumn{2}{|c|}{$\begin{array}{l}\text { Kadar BOD } \\
(\mathrm{mg} / \mathrm{l})\end{array}$} & \multirow{2}{*}{$\begin{array}{l}\begin{array}{l}\text { Penur } \\
\text { unan }\end{array} \\
(\mathrm{mg} / \mathrm{l})\end{array}$} & \multirow{2}{*}{$\begin{array}{l}\begin{array}{l}\text { Persent } \\
\text { ase }\end{array} \\
(\%)\end{array}$} \\
\hline & & $\begin{array}{l}\text { Sebelu } \\
\mathrm{m} \\
(\mathrm{mg} / \mathrm{l})\end{array}$ & $\begin{array}{l}\text { Sesuda } \\
\mathrm{h}(\mathrm{mg} / \mathrm{l})\end{array}$ & & \\
\hline 1 & $\begin{array}{l}\text { Pemeriksa } \\
\text { an I }\end{array}$ & 226,59 & 77,19 & 149,4 & 65,93 \\
\hline 2 & $\begin{array}{l}\text { Pemeriksa } \\
\text { an II }\end{array}$ & 210,36 & 73,60 & 136,66 & 64,84 \\
\hline 3 & $\begin{array}{l}\text { Pemeriksa } \\
\text { an III }\end{array}$ & 207,18 & 70,72 & 137,48 & 65,69 \\
\hline \multicolumn{2}{|c|}{ Rata-rata } & 214,71 & 73,83 & 141,28 & 65,49 \\
\hline
\end{tabular}

Tabel 2

Hasil Pemeriksaan Kadar COD Sampel Sebelum Dan SesudahPengolahan Biofilter Anaero Dan Aerob Dengan Media Papan pakis

\begin{tabular}{|c|c|c|c|c|c|}
\hline \multirow{2}{*}{$\begin{array}{l}\mathbf{N} \\
\mathbf{0}\end{array}$} & \multirow{2}{*}{$\begin{array}{l}\text { Pemeriks } \\
\text { aan }\end{array}$} & \multicolumn{2}{|c|}{$\begin{array}{l}\text { Kadar COD } \\
(\mathrm{mg} / \mathrm{l})\end{array}$} & \multirow{2}{*}{$\begin{array}{l}\text { Penur } \\
\text { unan } \\
\text { (mg/l) }\end{array}$} & \multirow{2}{*}{$\begin{array}{l}\text { Persen } \\
\text { tase } \\
(\%)\end{array}$} \\
\hline & & $\begin{array}{l}\text { Sebelu } \\
\mathrm{m} \\
(\mathrm{mg} / \mathrm{l})\end{array}$ & $\begin{array}{l}\text { Sesud } \\
\text { ah } \\
(\mathrm{mg} / \mathrm{l})\end{array}$ & & \\
\hline 1. & $\begin{array}{l}\text { Pemeriks } \\
\text { aan I }\end{array}$ & 680 & 160 & 520 & 76,47 \\
\hline 2. & $\begin{array}{l}\text { Pemeriks } \\
\text { aan II }\end{array}$ & 640 & 140 & 500 & 78,13 \\
\hline 3. & $\begin{array}{l}\text { Pemeriks } \\
\text { aan III }\end{array}$ & 610 & 100 & 510 & 83,60 \\
\hline \multicolumn{2}{|c|}{ Rata-rata } & 643,33 & 133,33 & 510 & 79,39 \\
\hline
\end{tabular}

\section{PEMBAHASAN}

1. Kemampuan Biofilter Anaerob Dan Aerob Media Papan Pakis Dalam Menurunkan Kadar Biochemical Oxygen Demand (BOD)

BOD ( Biochemical Oxygen Demand ) merupakan parameter yang penting untuk diketahui dalam menetukan kualitas suatu limbah cair. Pengukuran BOD dilakukan untuk mengetahui jumlah oksigen yang dibutuhkan oleh mikroorganisme untuk menguraikan atau mengoksidasi hampir semua senyawa organik terlarut dan sebagian senyawa yang tersuspensi dalam air limbah cair.

BOD (Biologycal Oxygen Demand) adalah salah satu parameter kimia yang sangat penting untuk diketahui dalam menentukan kualitas limbah cair, pada pengolahan air limbah pemotongan ayam Arninda dengan menggunakan media papan pakis dengan tiga kali pemeriksaan dengan waktu tinggal 11 jam, kandungan BOD limbah cair melalui pengolahan mengalami penurunan. Hal ini dapat disebabkan oleh lamanya penumbuhan bakteri, Karena selama proses penumbuhan bakteri telah banyak perubahan yang terjadi pada permukaan media papan pakis yang ada dalam zona anaerob dan aerob, telah diselimuti oleh lapisan mikroorganisme. Dengan tumbuhnya lapisan mikroorganisme tersebut maka proses penyaringan padatan tersuspensi maupun penguraian senyawa polutan yang ada didalam air limbah menjadi lebih baik.

Pada pengolahan air limbah pemotongan ayam Arninda dengan 
menggunakan media papan pakis dengan melakukan sebanyak 3 kali pemerikssan dimana kadar awal pemeriksaan 1 yaitu 226,59 $\mathrm{mg} / \mathrm{l}$ turun menjadi $77,19 \mathrm{mg} / \mathrm{l}$ atau dengan persentase $65,93 \%$, pemeriksaan 2 kadar awalnya $210,36 \mathrm{mgl}$ turun menjadi $73,60 \mathrm{mg} / \mathrm{l}$ atau $64,84 \%$ sedangkan pada pemeriksaan 3 kadar awal 207,18 $\mathrm{mg} / \mathrm{l}$ turun menjadi 70,72 $\mathrm{mg} / \mathrm{l}$ atau $65,69 \%$.

Jika dilihat dari kadar BOD tersebut hasil pengolahan dari 3 kali pemeriksaan hasilnya tidak jauh berbeda. Penurunan yang paling besar terjadi yaitu pada pemeriksaan 1 dengan persentase penurunan $65,93 \%$.

Hal ini dapat disebabkan karena kondisi suhu dan $\mathrm{pH}$ limbah masih dalam memenuhi baku mutu sehinggah dapat mendukung pertumbuhan mikroorganisme dalam menguraikan bahan organik. Suhu limbah yaitu $25^{\circ} \mathrm{C}$ dan $\mathrm{Ph} 7,6$.

Berdasarkan hasil kadar BOD dengan menggunakan media papan pakis di atas dari 3 kali pemeriksaan yang dilakukan hasilnya semua dapat memenuhi persyaratan baku mutu berdasrkan Keputusan Menteri Lingkungan Hidup nomor 02 tahun 2006 dimana kadar BOD maksimum yaitu $100 \mathrm{mg} / \mathrm{l}$.

Pada pengolahan pemotongan ayam media papan pakis yang yang telah dipotongpotong kecil disimpan pada bak aerob dan anaerob sehingga pada bak tersebut terjadi penguraian bahan organik. Bak pertama dalam pengolahan ini yaitu anaerob yang dipicu menguraikan bahan organik lebih besar yang selanjutnya dimaksimalkan oleh pengolahan pada bak aerob yang diberi aerator untuk menambah oksigen dalam limbah sehingga penguraian dapat maksimal. Media papan pakis dalam pengolahan ini memeliki sekat-sekat atau rongga yang dapat dijadikan pertumbuhan bakteri melekat dengan baik.

Proses pengolahaan anaerob menggunakan organisme yang aktif dimana oksigen tidak ada, dan proses ini ditujukan oleh prosesfermentasi metan. Proses selanjutnya terjadi pada bak aerob, sistem ini organisme yang menempel pada media filter pada proses aerob diperlukan pula aerator untuk mensuplai bakteri, udara berfungsi sebagai konsumsi bakteri agar dengan aktif dapat memakan kandungan organik dalam limbah. Lamanya waktu tinggal dan lamanya aliran limbah cair didalam sistem biofilter dengan media papan pakis, memberikan kesempatan partikel zat organik tersuspensi yang relatif besar mengendap. Dengan adanya pengendapan tersebutkadar BOD turun, karena jumlah zat organik yang harus didegradasi oleh mikroorganisme dalam limbah cair berkurang.

Tanaman pakis memiliki karakteristik media yang bersifat porous sehingga mudah menyimpan dan mengikat air, serta dapat mengalirkan kelebihan air yang tidak dibutuhkan sehingga tidak mudah basah dan tergenang air dan memiliki rongga-rongga untuk proses drainase dan aerasi yang baik (Holtum, 1959; Smith, 1971) dalam Hariyadi (2000).

Hasil penelitian ini sama halnya dengan penelitian yang dilakukan oleh Rully Rudal Syafruddin tahun 2013 menunjukkan bahwa kadar BOD limbah cair rumah pemotongan ayam setelah dilakukan pengolahan dengan biofilter Anaerob media sarang tawon dengan tiga kali replikasi didapatkan hasil penurunan kadar BOD sebanyak 55,37 \%, dari kadar sebelum $318,57 \mathrm{mg} / \mathrm{l}$ sesudah $141,35 \mathrm{mg} / \mathrm{l}$ sedangkan biofilter aerob hasil penurunan ratarata kadar BOD sebanyak $22,61 \%$ dari kadar sebelum 141,8 mg/l sesudah 109,80 mg/l.

Pada penelitian tersebut hasil penurunannya belum memenuhi persyaratan berdasrkan baku mutu karena kadar awal BOD sebelum pengolahan sangat tinggi sedangkan persentase penurunan sangat kecil.

2. Kemamapuan Biofilter Anaerob Dan Aerob Media Papan Pakis Dalam Menurunkan Kadar COD (Chemical Oxygen Demand)

Pada pengolahan air limbah pemotongan ayam Arninda dengan menggunakan media papan pakis dengan melakukan pemeriksaan sebanyak 3 kali.

Pada pemeriksaan 1 kadar awal COD yaitu $680 \mathrm{mg} / \mathrm{l}$ turun menjadi $160 \mathrm{mg} / \mathrm{l}$ atau $76,47 \%$, pemeriksaa 2 kadar awal turun menjadi $140 \mathrm{mg} / \mathrm{l}$ dari kadar awal $640 \mathrm{mg} / \mathrm{l}$, sedangkan pemeriksaan 3 kadar awal yaitu $610 \mathrm{mg} / \mathrm{l}$ turun menjadi $100 \mathrm{mg} / \mathrm{l}$ atau 83,60\% ada perlakuan yaitu $680 \mathrm{mg} / \mathrm{l}$ sesudah pengolahan $120 \mathrm{mg} / \mathrm{l}$ persentase $82,35 \%$.

Dari hasil pemeriksan kadar COD tersebut di atas dapat dilihat bahwa hasil penurunan terbesar terjadi pada pemeriksaan 3 yaitu $82,35 \%$. Berdasarkan hasil akhir setelah pengolahan dari 3 pemeriksaan yang dilakukan semua hasil penurunan sudah memenuhi baku mutu Peraturan menteri lingkungan hidup 

Nomor 02 Tahun 2006 dimana kadar maksimum yaitu $200 \mathrm{mg} / \mathrm{l}$.
Berdasarkan hasil yang di peroleh maka dapat diketahui bahwa semakin luas permukaan media dan semakin lama waktu kontak maka makin besar pula penurunan yang terjadi pada COD (Chemical Oxygen Demand) karena memungkinkan proses difusi dan penempelan molekul zat terlarut yang teradopsi berlangusng dengan baik.
Secara keseluruhan dari pemeriksaan yang telah dilakukan dengan menggunakan media filter papan pakis yang memiliki tekstur
biofilter anaerob dan aerob media papan pakis menggunakan waktu tinggal 11 jam dengan tiga kali pemeriksaan yang dilakukan kadar rata-rata BOD awal yaitu $214,71 \mathrm{mg} / \mathrm{l}$ rata-rata penurunan 73,83 $\mathrm{mg} / \mathrm{l}$ atau $65,49 \%$
b. Penurunan kadar COD limbah cair pemotongan ayam dengan menggunakan media papan pakis dengan menggunakan waktu tinggal 11 jam dengan tiga kali pemeriksaan dimana kadar awal COD rata-rata yaitu $643,33 \mathrm{mg} / \mathrm{l}$ rata-rata penurunan $133,33 \mathrm{mg} / \mathrm{l}$ atau $79,34 \%$ yang kasar sehingga dapat dimanfaatkan untuk menurunkan kadar COD (Chemical Oxygen Demand) pada air limbah pemotongan ayam. Apa bila air limbah yang di buang kebadan air dengan kualitas rendah, maka kadar oksigen akan menurun karena digunakan oleh bakteri untuk memproses penguraian. Apabila kadar COD (Chemical Oxygen Demand) tinggi maka akan timbul bau karena kandungan zat organik didalamnya oksigen tidak mampu lagi menguraikannya sehingga secara fisik dapat diketahui bahawa terjadi pencemaran.

\section{PENUTUP}

\section{Kesimpulan}

a. Penurunan kadar BOD limbah cair pemotongan ayam dengan menggunakan

\section{Saran}

a. Kepada pihak pengelola rumah pemotongan ayam sebaiknya membuat system pengolahan limbah cair dengan sistem biofilter kombinasi anaerob dan aerob dengan dengan waktu tinggal 11 jam dengan media papan pakis pada kondisi tertentu atau pada saat efesiensinya kurang efektif, karena peneliti menilai pengolahan jenis ini cukup efektif dalam menurunkan kadar BOD dan COD limbah cair rumah pemotongan ayam.

b. Diharapkan bagi peneliti selanjutnya, untuk mengkombinasikan media papan pakis dengan media saring lainya untuk memperoleh hasil yang lebih baik lagi.

\section{DAFTAR PUSTAKA}

Budiono Sugeng.2008.Bunga Rampai Hiperkes dan Keselamatan Kerja.Semarang : Badan Penerbit Universitas Diponegoro.

Jenie, B. S. L., \& Rahayu, W. P. 1996. Penanganan Limbah Industri Pangan. Yogyakarta: Kanisius.

Menteri Negara Lingkungan Hidup. 2006 . Peraturan Menteri Negara Lingkungan Hidup Nomor : 02 Tahun 2006 Tentang baku mutu air limbah pemotongan hewan

Nusa Idaman Said.(2011).Pengelolaan Limbah Domestik.Jakarta:BPPT.

Tjitrosoepomo, G., 1994, Morfologi Tumbuhan, Cetakan ke 8, Gadjah Mada University Pres,Jogyakarta 